\title{
Taxonomic notes on the polypore genera Antrodiella, Daedaleopsis, Fibuloporia and Phellinus
}

\author{
TUOMO NIEMELÄ
}

\begin{abstract}
NIEMEL Ä, T. 1982: Taxonomic notes on the polypore genera Antrodiella, Daedaleopsis, Fibuloporia and Phellinus. - Karstenia 22: 11-12.

The following new nomenclatural combinations for polyporaceous fungi are proposed: Antrodiella hoehnelii (Bres. ex Höhn.) Niemelä (Polyporus hoehnelii Bres.), A. onychoides (Egeland) Niemelä (Polyporus onychoides Egel.), A. romellii (Donk) Niemelä (Poria romellii Donk), Daedaleopsis septentrionalis (Karst.) Niemelä (Lenzites septentrionalis Karst.), Fibuloporia mucida (Pers. : Fr.) Niemelä (Poria mucida Pers. = Fibuloporia donkii Domański) and Phellinus tuberculosus (Baumg.) Niemelä (Boletus tuberculosus Baumg. = Phellinus pomaceus (Pers.) Maire). The backgrounds of these combinations are briefly discussed.
\end{abstract}

Tuomo Niemelä, Department of Botany, University of Helsinki, Unioninkatu 44, SF00170 Helsinki 17, Finland.

Some new nomenclatural combinations are proposed in this paper, to make them available in other publications. All except the last have already been used as provisional combinations in university teaching in Helsinki (Niemelä 1981a). Only short discussions are presented here besides the validations. It is hoped that the author can deal with these species more fully on some later occasion.

\section{Antrodiella Ryv. \& Johansen}

The description of this genus (Ryvarden \& Johansen 1980 ) is a sound solution to the problem of the correct generic treatment of the species of the so-called Polyporus semisupinus complex. The following species have already been discussed by Niemelä (1981b) and Kotiranta \& Niemelä (1981).

Antrodiella hoehnelii (Bres. ex Höhn.) Niemelä n.comb. Basionym: Polyporus hoehnelii Bresadola in Höhnel, Sitzungsber. Kaiserl. Akad. Wiss. Wien (Math.-nat. Kl., Abt. 1) 121: 344. 1912.

Antrodiella onychoides (Egeland) Niemelä n.comb. Basionym: Polyporus onychoides Egeland, Nyt Mag. Naturvidenskaberne 51: 92. 1913. The generic position has been discussed by Niemelä (1981b); for the type, see Egeland (1913) and Ryvarden (1976).

Antrodiella romellii (Donk) Niemelä n.comb. Basionym: Poria romellii Donk, Persoonia 5: 84. 1967. Lectotypus no. 910.262-883 (L, sel. Donk 1967). A good description of this species was presented by Eriksson (1949, as Poria byssina) and its taxonomy was extensively discussed by Donk (1967).

\section{Daedaleopsis Schroet.}

The species concepts vary widely in this genus. While some authors keep the whole European material within a single species, others prefer more restricted concepts. The northern taxon, discussed here (cf. Strid 1972), can be delimited rather well on the basis of the dichotomously divided lamellae, host tree Betula, isolated distribution, and the results obtained in crossing experiments with $D$. confragosa (Bolt. : Fr.) J. Schroet. and D. tricolor (Bull.) Bond. \& Sing. (David, in litt.).

Daedaleopsis septentrionalis (Karst.) Niemelä n.comb. Basionym: Lenzites septentrionalis Karsten, Not. Sällsk. Fauna Flora Fennica Förh. 8 (N.S. 5): 199. 1866 (Article preprinted 1866, volume published 1882), \& Bidr. Känned. Finlands Nat. Folk 25: 239. 1876. Type, see Lowe (1956).

\section{Fibuloporia Bond. \& Sing.}

The genus was described invalidly by Bondarcev \& Singer (1941) and validated by Singer (1944). Its limits were defined by Domański (1969) and ever since its description consensus has prevailed about the meaning of the generic name. This needs conservation, however, because the name of the original type ( $F$. mollusca (Pers.) Bond. \& Sing.) was later shown to mean quite a different species of the genus Trechispora (Cristella; Donk 1967). This left F. mollusca sensu Bond. \& Sing. unnamed. There is a name Poria muci- 
P. sajanensis is a wood-rotting fungus of conifers. Earlier, it has been reported on Abies sibirica, Larix gmelinii (L. dahurica), L. sibirica, and Picea abies ssp. abies and ssp. obovata (Parmasto 1962, 1967, Domański 1974, Strid 1981). The Finnish collection from Pinus sylvestris thus adds a new host to the list. The present find was made on a rotten log, left behind in a clear-cut area on a low fjeld top. The forests are very sparse there, consisting chiefly of Betula pubescens ssp. tortuosa, which is intermixed with Pinus and some of the northernmost populations of Picea abies. The same log also harboured Trichaptum laricinum (Karst.) Ryv. and still unnamed conifer-dwelling species of the Antrodiella semisupina complex.

Acknowledgements. I wish to thank Dr. Åke Strid (Stockholm) for sending me reference material. The English of this paper was revised by Mrs Anna A. Damström, M.A.

The work was supported by a long-term grant from the Academy of Finland.

\section{References}

Ahti, T., Hämet-Ahti, L. \& Jalas, J. 1968: Vegetation zones and their sections in northwestern Europe. - Ann Bot. Fennici 5: 169-211.
Anonymus 1975: Index of Fungi 4(10): 301-335.

Domański, S. 1969: Grzyby zasiedlające drewno w Puszczy Białowieskiej 10. Fibuloporia subvermispora (Pilát) Domański, comb. nov. i jej rozpoznanie. - Acta Soc. Bot. Poloniae 38: 453-464

- 1974: Mała flora grzybów 1(1). Basidiomycetes, Aphyllophorales: Bondarzewiaceae, Fistulinaceae, Ganodermataceae, Polyporaceae. - 316 pp. Warszawa \& Kraków.

Donk, M. 1960: The generic names proposed for Polyporaceae. - Persoonia 1: 173-302.

- 1966: Notes on European polypores 1. - Persoonia 4: 337-343.

- 1974: Check list of European polypores. - 469 pp. Amsterdam.

Hämet-Ahti, L. 1981: The boreal zone and its biotic subdivision. - Fennia 159: 69-75.

Jülich, W. 1981: Higher taxa of Basidiomycetes. - 485 pp. Vaduz.

Parmasto, E. 1962: Novye vidy i raznovidnosti gribov. Tremellales i Aphyllophorales. - Bot. Mater. Otdela Spor. Rast. Bot. Inst. Akad. Nauk SSSR 15: 125-137.

- 1967: Trutovye griby severa Sovetskogo Sojuza. - Mikol. Fitopatol. 1: 280-286.

Strid, §. 1981: Incrustoporia sajanensis (Parm.) comb.nov. (Polyporaceae), a taiga species new to Fennoscandia. -Wahlenbergia 7: 135-139.

Tortić, M. \& David, A. 1981: Skeletocutis jelicii nov.sp. (Polyporaceae). - Bull. Mensuel Soc. Linnéenne Lyon 50: $217-219$.

Accepted for publication

on May 13, 1982 